\title{
FUNCTIONAL RESULTS OF JEJUNAL REPLACEMENT OF LOWER OESOPHAGUS
}

\author{
BY \\ J. B. SELF \\ From St. Thomas's Hospital, London
}

(RECEIVED FOR PUBLICATION JULY 14, 1961)

Benign stricture of the oesophagus resulting from peptic oesophagitis has been treated in many ways and by various operations. Over the past three years in this unit, when the stricture has been judged to be permanent, the operation of choice has been resection of the stricture and replacement with a jejunal loop, replacing the stomach and the jejuno-gastrostomy below the diaphragm. The results to date of this procedure appear satisfactory, and an attempt has been made to assess this group more carefully although the follow-up period is still short.

The assessment has had three different aspects of function under review: the patient's ability to swallow, the nutritional state, and any post-cibal symptoms analogous to the dumping syndrome. These particular aspects were reviewed for several reasons. The ability to swallow is most important as dysphagia is the patient's chief complaint. One would expect it to be cured unless alkaline oesophagitis supervenes. It was hoped that a short loop of jejunum would produce insufficient succus entericus to cause this.

It was also supposed on theoretical grounds that nutrition would be maintained as the resection is limited and the whole stomach is retained. There is unlikely to be any defect in absorption and the patient might be expected to maintain normal weight.
The fact that the ingested food goes straight into a loop of jejunum might lead to dumping, as suggested by Maillard and Fekete (1960). They also point to the hazard of haemorrhagic jejunitis as a result of reflux into the loops. This is a possibility and may necessitate the use of some valvular anastomosis, as used by Lortat-Jacob (1958) for his competent oesophago-gastrostomy, and we have seen one case after replacement with a colonic loop.

Jejunal replacements for carcinoma have been excluded from this review as survival is short and malignant spread affects the nutritional state. Jejunal replacement has been used for malignant stricture for ten years at St. Thomas's Hospital.

The following seven cases of simple peptic stricture have been assessed. A standard set of questions was asked in order to assess the patient's ability to swallow, and to determine whether vomiting or regurgitation occurred and, if so, its relation to meals and its nature. The patient was also questioned as to the occurrence of postprandial symptoms and as to any change in bowel habit. A number of nutritional studies were carried out (Table). Besides those shown in the table, a glucose tolerance test, a barium swallow, and a full blood examination were performed on each patient.

TABLE

SEVEN PATIENTS INVESTIGATED FOLLOWING OESOPHAGO-JEJUNO-GASTROSTOMY FOR PEPTIC STRICTURE

\begin{tabular}{|c|c|c|c|c|c|c|c|c|c|c|c|c|c|c|c|c|c|}
\hline \multirow[b]{2}{*}{$\begin{array}{c}\text { Case } \\
\text { No. }\end{array}$} & \multicolumn{2}{|c|}{ Weight (st. lb.) } & \multicolumn{6}{|c|}{ Serum Electrolytes } & \multirow{2}{*}{$\begin{array}{c}\text { Haemo- } \\
\text { globin } \\
(\%)\end{array}$} & & & & \multirow{2}{*}{$\begin{array}{c}\text { Five-day } \\
\text { Faecal } \\
\text { Fat } \\
\text { (g./ } \\
24 \text { hr.)* }\end{array}$} & \multicolumn{3}{|c|}{ Plasma Proteins } & \multirow{2}{*}{$\begin{array}{c}\text { Serum } \\
\text { Alka- } \\
\text { line } \\
\text { Phos- } \\
\text { phatase }\end{array}$} \\
\hline & $\begin{array}{c}\text { Pre- } \\
\text { opera- } \\
\text { tive }\end{array}$ & $\begin{array}{c}\text { Post- } \\
\text { opera- } \\
\text { tive }\end{array}$ & $\begin{array}{c}\text { Iron } \\
(\mu \mathrm{g} \cdot ! \\
100 \mathrm{ml} .)\end{array}$ & $\begin{array}{c}\mathrm{Ca} \\
(\mathrm{mg} . \\
100 \mathrm{ml} .)\end{array}$ & $\mid \begin{array}{c}P \\
(\mathrm{mg} \cdot / \\
100 \mathrm{ml} .)\end{array}$ & 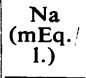 & $\underset{\substack{\mathbf{m E q} \\
1 .)}}{\mathbf{K}}$ & $\underset{\substack{\mathrm{Cl} \\
\text { l. })}}{\text {. }}$ & & & ilt & & & Total & $\underset{\text { min }}{\text { Albu- }}$ & $\begin{array}{c}\text { Glo- } \\
\text { bulin }\end{array}$ & \\
\hline $\begin{array}{l}1 \\
2 \\
3 \\
4 \\
5 \\
6 \\
7\end{array}$ & $\begin{array}{l}9 \cdot 0 \\
9 \cdot 2 \\
9 \cdot 10 \\
5 \cdot 9 \\
7 \cdot 7 \\
8 \cdot 5 \\
9 \cdot 6\end{array}$ & $\begin{array}{c}11 \cdot 0 \\
8 \cdot 12 \\
9 \cdot 10 \\
6 \cdot 10 \\
7 \cdot 0 \\
8 \cdot 5 \\
9 \cdot 9\end{array}$ & $\begin{array}{r}88 \\
51 \\
120 \\
140 \\
124 \\
139 \\
127\end{array}$ & $\begin{array}{r}8.5 \\
11 \cdot 1 \\
9.8 \\
10.0 \\
10.8 \\
9.8\end{array}$ & $\begin{array}{l}3 \cdot 2 \\
3 \cdot 7 \\
3 \cdot 0 \\
5 \cdot 0 \\
5 \cdot 0 \\
3 \cdot 9 \\
4 \cdot 4\end{array}$ & $\begin{array}{l}146 \\
138 \\
141 \\
133 \\
142 \\
139 \\
138\end{array}$ & $\begin{array}{l}4 \cdot 1 \\
4 \cdot 5 \\
3 \cdot 5 \\
4 \cdot 3 \\
4 \cdot 1 \\
4 \cdot 2 \\
4 \cdot 0\end{array}$ & $\begin{array}{l}100 \\
105 \\
105 \\
102 \\
103 \\
105 \\
101\end{array}$ & $\begin{array}{r}96 \\
96 \\
103 \\
86 \\
75 \\
99 \\
93\end{array}$ & $\begin{array}{l}- \\
- \\
- \\
- \\
-\end{array}$ & $\begin{array}{c}+ \\
+ \\
\cdots \\
+ \\
+ \\
+\end{array}$ & $\begin{array}{l}+ \\
- \\
- \\
- \\
- \\
--\end{array}$ & $\begin{array}{l}4 \cdot 8 \\
9 \cdot 9 \\
5 \cdot 7 \\
3 \cdot 0 \\
7 \cdot 7 \\
2 \cdot 5\end{array}$ & $\begin{array}{l}7 \cdot 3 \\
7 \cdot 0 \\
7 \cdot 0 \\
7 \cdot 1 \\
7 \cdot 9 \\
7 \cdot 6 \\
7 \cdot 0\end{array}$ & $\begin{array}{l}5 \cdot 5 \\
5 \cdot 1 \\
5 \cdot 2 \\
5 \cdot 2 \\
5 \cdot 2 \\
6 \cdot 1 \\
4 \cdot 8\end{array}$ & $\begin{array}{l}1.8 \\
1.9 \\
1.8 \\
1.9 \\
2.7 \\
1.5 \\
3.2\end{array}$ & $\begin{array}{r}9 \\
9 \\
12 \\
8 \\
7 \\
10 \\
11\end{array}$ \\
\hline
\end{tabular}

* Average daily fat in diet over five days varied from 108-166 g. 
These seven patients have varying lengths of history (3-35 years) and had varied treatment before being seen by us before the final oesophago-jejuno-gastrostomy. The following is a summary of their case histories.

\section{Case Reports}

CASE 1.-A woman, aged 67, had an eight-year history of regurgitation and dysphagia. She was treated with repeated dilatations of a stricture above a hiatus hernia. On September 29, 1958, she had a resection and jejunal loop replacement at the Brompion Hospital.

CASE 2.-A woman, aged 69, had had dysphagia and regurgitation for five years. Hiatus hernia and stricture were confirmed. On November 21, 1958, a resection and jejunal loop replacement was performed at St. Thomas's Hospital.

CASE 3.-A man, aged 65, had a haematemesis in 1958. Laparotomy at the County Hospital, Lincoln. revealed a duodenal ulcer. Gastro-enterostomy and devascularization of the stomach was carried out. Post-operatively he developed retrosternal pain. Achalasia was diagnosed and a retrograde dilatation attempted. Fibrous stricture was then diagnosed.

In 1959 he was referred to St. Thomas's Hospital. Hiatus hernia and stricture were confirmed and treated on September 8, 1959, by resection and jejunal loop replacement.

CASE 4.-A boy, aged 14, had been a bad eater since birth and had been in hospital from age 2 to 4 years. In 1958 he suffered from increasing vomiting and pain in the "throat." A barium swallow showed a hiatus hernia and stricture. He was admitted to St. Thomas's Hospital. On May 9, 1958, repair of the hernia was followed by dilatation of the stricture. In 1959 swallowing became worse again. Resection of the stricture and jejunal loop replacement with endto-side oesophago-jejunostomy was performed on October 27, 1959. Post-operatively the blind end dilated and caused difficulty in swallowing. On July 11, 1960, the blind end was excised and the oesophago-jejunostomy enlarged.

CASE 5.-A woman, aged 36, complained of vomiting after meals since the age of 10 months. In 1959 a smooth stricture was revealed at $34 \mathrm{~cm}$.; her dysphagia was getting worse. She was admitted to St. Thomas's Hospital and oesophagoscopy and biopsy showed a stricture with the lower oesophagus lined by columnar epithelium. Barium swallow showed no hernia. On October 28, 1959, resection of the lower oesophagus and stricture and jejunal loop replacement was performed.

CASE 6.-A man, aged 25, had complained of dysphagia since birth and had developed a stricture at $21 \mathrm{~cm}$. at the age of 3 years. This was treated by repeated dilatations at St. Thomas's Hospital. Aged 14, he had a two-thirds partial gastrectomy and dilatation of the stricture. After this he was much improved, but at the age of 25 symptoms recurred. Barium swallow and oesophagoscopy showed recurrence and progression of the stricture. On December 1, 1959, resection and jejunal loop replacement was performed.

CASE 7.-A woman, aged 65 , had had epigastric pain for one year. Para-oesophageal hernia and gastric ulcer were revealed on barium swallow. She was admitted to St. Thomas's Hospital and on May 5, 1959, repair of the hernia and upper partial gastrectomy was done, together with end-to-end oesophagogastrostomy. On January 7, 1960, the pain recurred. Oesophagoscopy showed ulceration at the anastomosis and barium swallow showed a penetrating ulcer at the same level. Resection of the stenosis and jejunal loop replacement was done on January 26.

\section{RESULTS}

All these patients can now swallow better than before. Four claim normal swallowing, one (Case 3) eats a little more slowly than before his gastric troubles started, and two (Cases 2 and 7) find some delay if meat is not fully masticated. Case 6 had some delay for several months, but this has cleared up.

Post-prandial symptoms and changes in bowel habit have been slight. Case 3 feels faint if he eats a heavy meal, and this is relieved if he lies down for 20 minutes; he has, however, had a gastro-enterostomy which might account for the dumping. Case 5 has sweating and palpitations after large meals. She had diarrhoea after the operation, but this cleared up after four months. Case 6 also had diarrhoea, but this has now settled to two bowel actions a day. He has had a partial gastrectomy as well and this may be relevant.

That dumping is absent is not surprising because the barium swallow in every case shows barium passing at once into the stomach and not remaining a measurable time in the jejunal loop, except in Case 1, where there is rather a long loop in the thorax with little peristalsis. In this case barium remains in the loop up to five minutes. Care in keeping the loop as short as possible and avoiding constriction at the hiatus is probably important in reducing the possibility of dumping. Björk and Norberg (1960) report considerable absorption from a colonic loop used to replace the oesophagus, but they replaced the whole stomach as well, and in their investigations they took steps to retain the test meal in the colonic loop in contrast to the investigations in our patients where barium shows rapid transit to the stomach.

Jejunitis and oesophagitis have not caused symptoms in these cases although positive occult bloods have occurred in two cases. 
Failure to gain weight consistently has been disappointing and is not explained. None of the patients has lost much weight since operation. A normal weight in most cases is difficult to assess, as three have had trouble since childhood and Case 3 also has a gastro-enterostomy. The other three are not underweight for their height and sex and had not lost weight pre-operatively. The table shows normal values for serum iron, good haemoglobin values, and, together with a normal blood picture, suggests normal absorption of iron and vitamin $B_{12}$.

Glucose tolerance curves are within normal limits, showing no unduly rapid absorption from the loop.

Plasma proteins are within normal limits in each case as are the electrolyte readings and the serum alkaline phosphatase. In each case the figures for faecal fat are well below $10 \%$ of the ingested fat which is usually taken as the upper limit of normal. This is better than the values found by Hays and Clark (1960) after total gastrectomy and replacement with a jejunal stomach; this is to be expected as the stomach is retained.
The period of follow-up is short, but so far no defects in nutrition have appeared.

\section{CONClusion}

Nutritional functional studies have been done on seven patients who have had jejunal replacement of the lower oesophagus for benign stricture.

This seems to be a reasonably satisfactory operation for benign stricture of the oesophagus. It is a time-consuming, but not a technically difficult, operation. Nutrition and the functional results are good. Competent oesophago-gastrostomy, as described by Maillard and Fekete (1960), is a simpler operation and, if consistently satisfactory. might supersede jejunal loop replacement in many cases, but it does place part of the stomach in the thorax which, in every other operation. has led to further oesophagitis.

I would like to thank Mr. N. R. Barrett for permission to do this work on his cases.

\section{REFERENCES}

Björk, V., and Norberg, B. (1960). Ann. Surg., 152, 1049

Hays, R. P., and Clark, D. A. (1960). Ibid., 152, 864.

Lortat-Jacob, J. L., Maillard, J. M., and Fekete, F. (1958, M M'm. Acad. Chir., 84, 840.

Maillard, J. N., and Fekete. F. (1960). Poumon, 16, 519 